\title{
The Biographers' Encounter with Jorge Luis Borges: Authentic or Total?
}

\author{
Ceyda Elgül
}

\begin{abstract}
This study sets out from the mutual concerns that biographers and translators face during the process of recreating a source for a new audience. It presents translation and biography writing as analogous forms of rewriting. Both biographers and translators are compelled to overcome the dilemma of the truth of the source vs. the authenticity of the rewrite. This requires them to consider matters such as fluency, (in)visibility, objectivity, fullness, accuracy, and competitiveness. Although each biography and translation offers unique solutions to these matters, they propose themselves as the "total"-exact, transparent, ultimate-representation of the source. Hence the rewriter's claim to authenticity. Based on this conceptual framework, in this paper I study the biographies Jorge Luis Borges by Jason Wilson and The Man in the Mirror of the Book by James Woodall as "authentic translations" of Jorge Luis Borges that aim to be the "total" English-language version of Jorge Luis Borges' life story. I discuss the subjectivities the biographers manifest in their works and the way in which each biography seems to present itself as total by highlighting different qualities depending on its biographer's agency.
\end{abstract}

Keywords: rewriting, agency; authenticity; biography as translation; Jorge Luis Borges

Résumé: Ce travail de recherche est né des préoccupations communes que les biographes et les traducteurs rencontrent lors du processus de re-création d'une source pour un nouveau public. La traduction et l'écriture de biographie sont présentées comme étant des formes analogues de réécriture. Les biographes au même titre que les traducteurs doivent aller au-delà du dilemme vérité de la source/authenticité de la réécriture. II leur faut alors s'intéresser à la fluidité, à l'invisibilité/visibilité, à l'objectivité, à l'entièreté, à la précision et à l'esprit de compétition. Biographie et traduction ne traitent pas ces aspects de la même manière, cependant les deux activités considèrent être des représentations " totales " (exacte, transparente, ultime) de la source. D'où la revendication d'authenticité de la part de celui qui réécrit. Sur la base de ce cadre conceptuel, dans cet article, j'étudie les biographies Jorge Luis Borges de Jason Wilson et The Man in the Mirror of the Book de James Woodall en tant que traductions authentiques de Jorge Luis Borges et qui visent à être la version anglaise " totale " de l'histoire de vie de Jorge Luis Borges. Je parle des subjectivités que les biographes manifestent dans leurs travaux et la façon dont chaque biographie semble devenir totale par le biais de la mise en valeur de différentes qualités en fonction du biographe.

Mots clés : réécriture, agency; authenticité; biographie en tant que traduction; Jorge Luis Borges

Resumo: Este estudo parte de preocupações mútuas que biógrafos e tradutores enfrentam durante o processo de recriação de uma fonte para um novo público. Apresentam-se a tradução e a escrita biográficas como formas análogas de reescrita. Tanto biógrafos quanto tradutores são obrigados a superar o dilema da verdade da fonte versus a autenticidade do texto reescrito. Isso solicita que considerem questões como fluência, (in)visibilidade, objetividade, abrangência, acuidade e competitividade. Embora cada biografia e tradução ofereçam soluções únicas para esses problemas, apresentam-se como a representação "total" - exata, transparente, final - da fonte. Daí a reinvindicação de autenticidade por parte do re-escritor. Com base nesse modelo conceitual, neste trabalho, estudamos as biografias Jorge Luis Borges, de Jason Wilson e The Man in the Mirror of the Book, de James Woodall, como "traduções autênticas" de Jorge Luis Borges, que se pretendem versões "totais" da história de vida do autor, em inglês. Discutimos as subjetividades dos biógrafos, manifestas em seus trabalhos e o modo como cada biografia parece se apresentar como total através da ênfase em diferentes qualidades, dependendo do que o biógrafo deseja agenciar.

Palavras-chave: reescrita; agência; autenticidade; biografia como tradução; Jorge Luis Borges

Resumen: Este estudio parte de las inquietudes mutuas que tanto biógrafos como traductores enfrentan durante el proceso de recrear un texto fuente para un público lector nuevo. En él se presentan la traducción y la redacción de biografías como formas análogas de reescritura. Tanto los biógrafos como los traductores se ven en la necesidad de resolver el dilema de la veracidad de la fuente versus 
la autenticidad del texto reescrito. Esto les exige tomar en cuenta aspectos como la fluidez, (in)visibilidad, objetividad, integridad, exactitud y competitividad. Si bien cada biografía y traducción ofrece soluciones únicas a estas cuestiones, cada cual se plantea a sí misma como la representación "total"-exacta, transparente, definitiva - de la fuente. De ahí la reivindicación de autenticidad de quien reescribe. Con base en este marco conceptual, en este artículo se estudian las biografías Jorge Luis Borges de Jason Wilson y The Man in the Mirror of the Book de James Woodall como "traducciones auténticas" de Jorge Luis Borges que apuntan a ser la versión en inglés "total" de la historia de la vida de este autor. Analizo las subjetividades que los biógrafos revelan en sus obras y la forma en que cada biografía parece presentarse como total al destacar cualidades diferentes según la agencia del biógrafo.

Palabras clave: reescritura, diligencia; autenticidad; biografía como traducción; Jorge Luis Borges

This paper surveys how two English-language biographers of Jorge Luis Borges, namely James Woodall and Jason Wilson, reconstructed the Argentine writer's image for the English-language audience in unique ways. Their process of finding Borges might remind us of the writer's short story "The Library of Babel" in which several pilgrims are stuck in a Library-of-Everything searching for the "total book". In the story, the total book stands for an impossible: It contains every possible version of every book, written and unwritten. We are not informed exactly what these book-lovers would do with this total book after finding it, or whether they would ever find it. So the total book remains as a mysterious and fuzzy image of the ideal that the reader is to reconstruct in his own mind. Therefore, as much as universal and infinite, it is local and individual.

In this paper, I begin with the idea that, rather than actually finding the total subject, the biographer's task is to convince the reader that he has found it. And this illusion, which claims to bridge the regional and temporal gap between the foreign subject and the target reader in the most believable way, requires the biographer to tackle with some concerns that are very similar to those of the translator, such as fluency, (in)visibility, fullness, accuracy, and competitiveness. Like a translator, the biographer creates his total and all-encompassing representation of the source subject with his unique and peculiar solutions to all these aforementioned matters. For this reason, I adopt an approach that assumes biography writing and translation to be analogous forms of rewriting, and propose The Man in the Mirror of the Book (1996) by James Woodall and Jorge Luis Borges (2006) by Jason Wilson as "authentic translations" of Jorge Luis Borges' life story that are each presented as the "total" representation of the source. I will demonstrate how each biography adopts this total image-which is assumed to be the ideal, exact, ultimate one-by manifesting different qualities depending on the biographer's agency.

This approach expands on André Lefevere's view of rewriting that highlights the seminal role of translation, editing, anthology, criticism and biography in the reception of foreign images-whether in the form of a historical figure/text, or of a foreign cultural product-by the target audience. As the scholar proposes, these secondary forms of literary activities by no means play an "ancillary" role, as most readers consume literature as rewritten by its rewriters (Lefevere 4). These agents create images of writers, works, periods, and genres that can reach more people than their corresponding realities did (5), which is why these forms of literary production should be studied in relation to ideology and agency. 
Lefevere's notion of rewriting that views biography and translation as analogous is a useful point of departure for this study. In fact, an investigation of the role of Jorge Luis Borges' English-language biographers in the construction of the author's global image might fit well into Lefevere's concept of ideology in rewriting. However, this study limits its focus to agency and considers the biographers' individualities hidden behind the illusion of total representation. Lefevere's framework is used to demonstrate the muted differences between the rewrites, which are the biographies, and their corresponding reality, which is Borges' life story.

Just as translation poses the dilemma of the untouchable source text vs. the translator's interpretation, biography offers its reader the juxtaposition of facts against the biographer's art. In his approach to biography, Gerald P. Mulderig states that "a biography can succeed only if the biographer makes the reader believe in its possible truth" ("Rhetorical" 44). The authenticity of a biography is closely related to its believability, which is why studies of biography could shift their focus from questions of accuracy and truth to the rhetorical features used by the biographer to make the reader believe in the biography's credibility (39). Authenticity requires a move away from the data out of which the biographical narrative is constructed towards the reader. The reader might be aware of the fact that "biographical narratives at best only approximate objective reality"; yet still, the biographer is expected to efface the idea of partiality and proximity and make the reader believe that the product is total (40). All in all, from Mulderig's perspective, "truth" is less important than "apparent truth", and the ultimate goal of every biographer is to "win the reader's assent to the validity of the image of the subject that the biography presents" (40). What goes hand in hand with this idea of winning the reader's assent, as I suggest, is competitiveness, which is inherent in every biography. This is one of the major motives behind the production of multiple biographies of the same persona. Though they all tell the life story of the same individual, these works compete for recognition as the ultimate version of their source through the illusion of presenting the truth as it is.

Mulderig's theory of believability in biography focuses mainly on the rhetoric of the biographical product, presenting the biographer's narrative as a site that manifests: 1) how the biographer establishes a relationship with the reader by balancing his overt contributions with his indirect presence in the text; 2) the characteristics of the biography's subject that the biographer foregrounds in order to construct a vivid, fleshand-blood image in the reader's mind; and 3) emplotment, that is, how the subject is situated in the historical context ("Rhetorical" 42-43). I expand on this framework for biographical narrative and its believability, whose components might remind us of the fluency of the translation product and the invisibility of the translator, by including contextual elements such as publishing policy, reception, and the expertise of the rewriter in the scope of my examination. Put differently, I propose that the "believability" of the biographical narrative interacts with a number of contextual features of the rewrite, which ultimately triggers an "illusion of reality" in the reader's mind. Therefore, the term "illusion of reality", which tends to encompass both textual and extra-textual features of rewrites, will help me to trace the presence of the biographers in their "authentic-but-total translations" of their subject's life story.

The illusion of reality in biographies and translations simply aims to convince the reader that the rewrite is an exact version of its source. Because it entails a wide range of textual and extratextual features, and each rewrite presents an illusion of reality with its unique points of strength, I propose two types of this illusion of reality: "illusion of immediacy" and "illusion of intactness". The former foregrounds the 
rewriter's style and rhetorics, as well as his selection of intelligible material, and offers the reader a supposedly immediate and unmediated encounter with the source text/subject. In immediate narratives, rewriters tend to bring the source to the fore through fluency and readability. In most cases, these narratives require their rewriters' interventions to be as indirect as possible. The invisibility of the rewriter expected in this context can be observed both in the main text and in paratexts, and even in reviews. Needless to say, there could be several reasons behind the biographer's choice of the illusion of immediacy: it might be to conceal the gap between the biographer and his source, which tends to be the case in works produced by agents approaching their source from a certain distance; it might be to make the foreign product as available-and therefore as penetrable-as possible; or it might be to target a general readership that consumes such literature for non-professional reasons.

The second form of illusion, the illusion of intactness, encompasses a range of ideas related to the content and context of the rewriting, such as the accuracy, objectivity, and reliability of the product in question. It tends to highlight the material used and omitted in the reconstruction of the source as the rewrite's strong point. The matter of objectivity is also observable at the stylistic level. As the reliability of the data used, and of the rewriter's way of organizing that data, is less likely to be questioned if the rewriter is considered an expert in the field, I propose the rewriter's expertise as an element of the illusion of intactness as well. In my framework, the term "expert" could also refer to translators who know the source text writers and biographers who personally know their subjects. All in all, despite presenting an illusion of reality, works with the illusion of intactness do not require the rewrite to be unmediated. On the contrary, the reader might even enjoy the expert-rewriter's company during his encounter with the source text/subject. Therefore, as in the context of translation, the biographer's expertise tends to grant him a kind of freedom and visibility, as well as a certain degree of reliability, which non-expert biographers are not given.

Having set out my framework, which presents translation and biography writing as analogous means of rewriting whose ultimate objective is to achieve an illusion of reality, I will now outline the forms of illusion employed in Jorge Luis Borges and The Man in the Mirror of the Book and explore the authenticity of each work with a focus on its producer's agency.

\section{The Illusion from the Outset: Publishing Contexts, Paratexts, and Reception}

The Man in the Mirror of the Book by James Woodall was published in 1996 with quite an explicit objective: to commemorate the tenth year of Borges' death. ${ }^{1}$ The biographer stresses this in the very first sentence of his foreword (xxiii). Within one year, the book seventeen editions of the book had been published in the UK and US. Today, TMMB is the most translated biography of Jorge Luis Borges. Some of the languages in which the work has appeared are: Turkish (1997), Spanish (1998), German (1999), Chinese (1999), Polish (2001), and Japanese (2002).

\footnotetext{
${ }^{1}$ Other biographies published in 1996 were Georgie (1899-1930): Una vida de Jorge Luis Borges by Alejandro Váccaro and Borges. Esplendor y derrota by Maria Esther Vázquez. In addition, Borges: Biografía total by Marcos Ricardo Barnátan (first published in 1995), Los dos Borges: Vida, suenos, enigmas by Volodia Teitelboim (first published in 1995), and the biographical work Genio y figura de Jorge Luis Borges (first published in 1964) by Alicia Jurado were all reprinted on the tenth anniversary of Borges' death.
} 
Hodder \& Stoughton is one of the leading private publishers of popular literature in the UK. In addition to being home to many best-selling authors, it has presented the life stories of a diverse range of figures from political history and popular culture in the form of biography or autobiography. Its repertoire includes the biographies of Queen Victoria, Winston Churchill, Mustafa Kemal Atatürk, Amy Winehouse, Beyoncé, Kurt Cobain, and Freddie Mercury, as well as figures in sports, business, acting, religion, members of the royal family, and so forth. The list seems to be in keeping with a publisher aiming for the widest reading audience possible. In other words, the "believability" of these biographies would be expected to be adapted to readers of commercial literature.

This context of production could be associated with Lawrence Venuti's theory identifying the commercial repertoire of translated literature in contemporary AngloAmerican culture with fluency and readability of the narrative. According to Venuti, the "illusory effect" perpetuated by fluency "conceals the numerous conditions under which the translation is made", and demands "invisible" translators ("Invisibility" 16). When we take a look at the reasons behind this tendency, as the scholar observes, we see that this "valorization of immediate intelligibility" and "dominance of transparency" in contemporary writing has economic motives (19). Fluency, after all, contributes to the sales of cultural products. In addition to appealing to a wider audience, fluent books are read and finished rapidly, which makes the reader buy more of them.

Now I will examine which parts of TMMB adapt to this norm of fluency that goes hand in hand with the rewriter's invisibility. From the outset, TMMB seems to present the work as a product in the above-mentioned context of commercial literature. There is an observable focus on the biography's subject that leaves the biographer behind the stage. On the front cover, there is a well-known photo of Jorge Luis Borges: an erudite old man holding a walking stick-a common reference to his blindness, elderliness and wisdom - with a self-confident posture and a half-smile on his face. We see the title followed by the name of the biography subject and the biographer. The name of the latter is written in a smaller font-size. The back cover presents a quotation by George Steiner that basically praises Borges, the biography's subject. So far, Woodall is much less visible in his biography than his subject.

As for the front and back flaps of the book, after a two-paragraph presentation of the subject, the biographer is introduced in the middle of the third paragraph, within the presentation of the biography itself. It reads as follows:

THE MAN IN THE MIRROR OF THE BOOK is the first biography to be written in English since Borges died, and from it emerges a picture of a complex man who neither courted fame nor ever acknowledged the literary revolution he set in train. Based on first-hand research in Buenos Aires, James Woodall's portrait depicts a Borges the world never saw: the young pamphleteering poet obsessed by Walt Whitman and Argentine slang; the sexually timid intellectual falling disastrously in love just as he was writing his finest prose; the guru of Latin-American letters whose sole aim in old age was domestic happiness. Throwing new light on the background to the stories and the poetry, James Woodall also looks at Buenos Aires itself, and at the two grand obsessions of Borges's life: his celibate love of women, and his loathing of Argentina's most charismatic dictator, Juan Perón. (Woodall, front and back flaps) 
This presentation of the biography mentions the biographer with a focus on his "firsthand research in Buenos Aires", the new information that he shares on the background to the stories and poetry, and his selection of interesting (and in fact scandalous) material about Borges' life. However, in the following paragraph, all the interesting material owes its presence in the biography to Jorge Luis Borges: The book is a "timely portrait" of a figure of literature "whose magnificent capacity to startle and disturb remains as bright today as it was at the height of his powers" (back flap). The note tends to suggest that, more than James Woodall, it is the biography's subject himself who bridges the gap between himself and the target reader with his own capacity to startle and disturb even today.

The four-paragraph presentation of the biography and its subject, which mentions the biographer in a way that contributes to the visibility of the subject rather than to the visibility of the biographer, is followed by a short paragraph on James Woodall right below his photo:

James Woodall has written on theatre, music and literature, for, amongst others, The Times, the Daily Telegraph, the Observer and GQ magazine. His first book, on flamenco, was published in 1992. He lives in Berlin. (Woodall, back flap)

Until TMMB came out, Borges' life had mostly been written about either by important figures of literature (Marcos Ricardo Barnátan, Volodia Teitelboim, Alejandro Váccaro, Emir Rodríguez Monegal), or by his close acquaintances (María Angélica Bosco, María Esther Vázquez, Alicia Jurado, Miguel de Torre Borges, Ulyses Petit de Murat, Roberto Alifano, Estela Canto, Willis Barnstone). These individuals themselves were presented as a distinguishing feature of the biographies they wrote, acknowledging the norm that expertise in or an acquaintance with the subject added to the sense of reliability of the biographical representation. James Woodall, on the other hand, was a freelance journalist and editor who had published a book of travel writing titled In Search of the Firedance: Spain Through Flamenco (1992) at the time TMMB was published. He specialized in international arts, mainly theatre and dance. He could be considered a typical freelancer, with his topics ranging from copyediting, proofreading and blurb writing, to web design and radio broadcasting. He speaks French, Spanish and German. After writing the biography of Borges, which had required him to travel back and forth Argentina and Europe, he settled in Berlin. Given this background, it is questionable whether stressing Woodall's agency would have laid the foundations for this form of illusion based on the biographer's reliability. However, the material that the biographer shares about himself and his life-writing process in the sections that grant him relatively more freedom, such as the "Acknowledgements" and the "Foreword", might change our opinion about him.

Until embarking on the biography, Woodall had little to do with Latin American culture, so the spatial and temporal distance between himself and his subject was substantial. For many readers, this would not make him a very good choice of biographer, and an alternative solution would need to be found to deal with his unfavorable position. As suggested above, the relatively silent and invisible position of the biographer on the cover, as well as on front and back flaps, seems to have been the solution in the case of $T M M B$. 
However, as mentioned, Woodall takes advantage of the freedom the "Acknowledgements" section grants him and compensates for the gap between himself and his subject by highlighting his contacts with academia and the publishing world (xi-xvi). In addition to receiving help from Borges' translator Norman Thomas di Giovanni and the Borges scholar Jason Wilson, the biographer seems to have used his skills as a journalist, as well as his degree from Oxford, to connect with the Borgian société in Argentina and abroad. His list of interviewees include Maria Kodama, Maria Esther Vázquez, Estela Canto, Alicia Jurado, Jorge Helft, Borges' literary agents in Europe and in the US, the US-based Borges translator Alastair Raid, and the Peruvian novelist Mario Vargas Llosa.

The distance between James Woodall and his subject might have silenced the biographer in certain sections of the biography, but it contributed to the perception of authenticity of $T M M B$ in several ways. The feedback from prestigious media sources in the UK and the US presented the biographer's distance from his subject as an advantage. For instance, in his review for The New York Times, Roberto González Echevarría described the biography as "the best general biography now available on this influential figure." The scholar praised Woodall's meticulous research and pointed out that, because Woodall was not a scholar of Latin American literature, he managed "to tap the Borges industry without being caught up in the effort to turn his subject into a monument" (González Echevarría "Man"). Thus, his distance from Borges enabled him to overcome some of the traps that expert biographers could not.

As I will demonstrate below, Woodall's "general" presentation of Borges, which presumably appeals to a non-professional reader, is realized with a certain degree of ease in the biographical narrative. Here the term "ease" basically refers to making the foreign product available to the reader with the inclusion of basic information, as well as of fluent, readable and vivid depictions. Therefore, it is a matter that concerns both content and form.

The peculiar characteristic of Woodall's narrative implied in Roberto González Echevarría's review-which could be described as "ease"-attracted the attention of Ilan Stavans as well. This critic also proposed the observable distance between Woodall and his subject as an advantage, because as an outsider, Woodall managed to avoid getting lost in the labyrinth of forking intellectual paths. To him, though the oversimplifications in the book might "strike the specialist as an innocent performance", the biographer's ease "makes Borges' dreams and nightmares accessible to us"; therefore, the work could be considered "a compass" that could lead the reader to the writer ("Bi(bli)ographies" 65). However, the ease in TMMB did not win the approval of every critic. An anonymous review in The Economist, for example, found Woodall's imagery "blinding" because it did not use Borges' literature as a starting point ("The Man" 7). Surely the "ease" in biography does not necessarily make it a "blinding" representation of the source. However, author-biographies that take the subject's work as a primary reference tend to appeal to a relatively more professional reader whose top priority in biography is not ease in content and style. For that reason, some readers might identify "ease" as a secondary quality in biography, and it could even be regarded as a basis for a "blinding" representation, which seems to be the case in this anonymous review.

Another aspect that reviews of the book noted was Woodall's melancholic and sad portrayal of Borges. In his article for The Observer, Adam Mars-Jones ironically stated that the biographer's main achievement was to show Borges as "sadder and more confused outside his art than the world could guess" (15); in Contemporary 
Review, Nicholas Wong pointed at how the biography depicts the "magnificent reader" as a man who is incapable of reading the human heart ("The Man"). No doubt all these commendations and criticisms of the biography are related to Woodall's idiosyncratic selection and organization of the material at hand. Both the aforementioned sad image drawn in the biography and the way the biographer reveals his own political ideals in his descriptions of his subject's standpoint could be taken as the traces of Woodall's persona concealed behind the biography's illusion of transparent representation. The critics might be aware that the biographer's selection is subjective, yet it is questionable whether they would welcome more frequent and visible intervention by the biographer in the narrative.

At this point, a review that concerns Woodall's selection of material and his direct intervention in the narrative is worth noting. David Sexton's article in The Spectator describes $T M M B$ as "admirably straightforward and unassuming, except on political matters" (29). In the biography, Woodall tends to object to Borges' views on the Latin American Revolution, the Cuban Revolution and the 1967 Arab-Israeli war, which seems to have bothered Sexton. This reaction reminds us of the common assumption that the biographer is to be invisible and has to identify his views with those of his subject. As the "translator" of his source, he is faced with the paradox of not being permitted to interfere in the narrative that he constructs with his own subjectivities.

Jason Wilson's Jorge Luis Borges was produced in a very different context. Published in 2006 by the UK-based publishing house Reaktion Books, the book is quite concise compared to its 333-page counterpart: just 173 pages long. Wilson's biography was commissioned to be a part of a special series entitled Critical Lives. By the time the Borges biography was published, the series had introduced the life-stories of such cult names of the modern period as Jean Genet, Michel Foucault, Pablo Picasso, Marcel Duchamp, and Jean-Paul Sartre. Critical Lives turned out to be a gigantic project of life writing, with a total of sixty-seven biographies by 2015 . Unlike H\&S, which presented the life stories of individuals associated with popular culture, Reaktion defined its objective as to "present the work of leading cultural figures of the modern period" (Wilson tag). It is also worth mentioning that in this project Reaktion only worked with biographers who have academic and/or professional experience related to their subjects.

The UK edition is the only version of $J L B$ in the English language. The biography has been translated into Portuguese (2009) and Turkish (2011). It follows the simple and concise visual of the publisher's series. Unlike a commercial biography, it has no picture of the subject on the cover; instead, what visually represents Jorge Luis Borges is a small picture of a hand softly touching the books on a library shelf. We could reasonably assume this to be a reference to Borges' well-established image as a bibliophile. Yet this simplicity and indirectness of the visuals on the cover might also imply that the intended readers of the work are bibliophiles as well.

As for the presentation of the biographer in the book, the blurb presents a oneparagraph bio of Jason Wilson. His academic expertise in Latin American literature is stressed and the books he has published about the region are listed. Therefore, unlike James Woodall, who had only his name on the cover of his biography, Jason Wilson is visible on the cover with a reference to his expertise as part of his work's unique value. However, it could also be argued that, since expertise adds to the believability of the biography and contributes to the work's image as objective representation, the presence of Wilson on the back cover as an expert biographer serves the illusion of 
reality in $J L B$, more than adding to the visibility of the biographer as a separate individual. In addition, the bio-note tends to focus on Wilson's scholarly work on Borges and Argentina, without mentioning his personal experience in the region as a Buenos Aires inhabitant, or porteño, as they call themselves. As the blurb suggests, by means of his academic persona, Wilson could "restore" the Argentine roots of Borges by exploring his "tumultuous early life in the streets and cafes of Buenos Aires" and charting "his literary friendships, love affairs and travels".

Jason Wilson is a Latin American scholar at University College London. He has taught courses on diverse topics related to Spanish and Latin American culture and literature. Writers he has researched include García Lorca, Pablo Neruda and Octavio Paz. In addition to his contributions to various journals and literary councils, he is a member of the jury for the Premio Valle-Inclán translation prize. He has also translated works that are either from or about Latin America, such as: Itinerary by Octavio Paz, Conversations by Borges and Osvaldo Ferrari, and Personal Narrative of a Journey to the Equinoctial Regions of the New Continent by Alexander von Humboldt. As a scholar, he has published his translations with informative introductions. He has also published works on South American writers (Octavio Paz, A Study of His Poetics; A Companion to Pablo Neruda: Evaluating Neruda's Poetry); investigations on specific regions (Traveller's Literary Companion to South and Central America; The Andes: $A$ Cultural History; Buenos Aires: A Cultural and Literary Companion; Buenos Aires); and a bibliographical examination of Latin American literature in English translation ( $A n A$ to $Z$ of Modern Latin American Literature in English Translation).

Having written about one of the world's most famous porteños (Borges) and published two volumes on Buenos Aires itself, Wilson manifests a particular interest in the Argentine capital. This partly has to do with the fact that he lived in Argentina in the 1970s. He married a porteña and regards himself as a local who speaks Spanish with the porteño lilt. In addition to this personal background, as reflected in an article that appeared in The Independent, Wilson is a seminal figure in the field of Borges criticism. In this article, Wilson introduces Borges as an individual who "formed part of the commercial blossoming of Latin American fiction in the heyday of Che Guevara and the Cuban Revolution" ("Gaucho Club"). After revealing how the 1970 Penguin edition of Labyrinths perpetuated this misrepresentation with a painting called Havana on its cover, he criticizes Borges' translators and publishers for stripping the master of his Buenos Aires roots. In the same article, the scholar corrects the translators who have recurrently mistranslated words with specific Argentine connotations. Thus, in contrast with the biographer of $T M M B$, Jason Wilson was already well-informed about Borges and Buenos Aires long before he embarked on his biography. As a British scholar, he had already shortened the gap between himself and his Argentine subject with his personal and professional experience. Still, his appearance in the biography does not seem to endanger the illusion of reality of the rewrite, which tends to be perpetuated through an illusion of objective representation, or intactness.

As for the reception of $J L B$, many critics in Argentina and abroad appreciated Wilson's proficient knowledge of the latest currents of Borges criticism, that is, his focus on Borges' Argentineness, rather than presenting him as a global figure. In his review for The Times Literary Supplement, Martin Schifino describes the book as "a balanced and fresh approach" owing to Wilson's "impatience with critical clichés" (27). Similarly, Edna Aizenberg applauds Wilson's new-and-Argentine way of studying Borges. For her, the presentation of "Borges the porteño" in this "tightly-knit biography" 
made "Borges the Argentine come through, maybe more real than intended" ("Jorge Luis Borges" 443).

However, the biographer's near accurate representation, which is presumably the result of his expertise, does not seem to grant him the freedom to put forward his own subjective opinions on his subject. For instance, despite highlighting Wilson's competence in reading Borges biographically, Martin Schifino mentions the biographer's "harsh" judgments of the master's "laziness" after he went blind (27). Similarly, according to lan Pindar's article in The Guardian, despite the presence of good humor that slips through in the master's "magnificent fictions", the biographer's emphasis on "Borges' desamor" makes JLB "a rather sad book" ("Jorge Luis Borges"). Lon Pearson stressed Wilson's failure to understand "or, perhaps, to convey to the reader" some of the historical issues related to Perón's oppressive treatment of the Borges family (230), and also identifies Wilson's insufficient attention to Borges' first marriage as a limitation.

The analysis of paratexts and reviews outlined above reveals that $T M M B$ and $J L B$ manifest the subjectivities of their biographers in different ways, which have to do with the forms of illusion of reality they present. The illusion of reality in these biographies is also in harmony with the publishing contexts. From the outset, published as a contribution to a repertoire of commercial literature, TMMB offers the reader an illusion of an unmediated encounter with the source, which I call the illusion of immediacy. The cover of the book does not present any information about the biographer James Woodall apart from his name. This might be a publishing strategy to conceal the distance between the biographer and his subject. However, before the text itself begins, Woodall shares his writing process with the reader, assuring the reader that he did his research well and met the right people. In fact, Woodall's status as a distant biographer attracted the attention of the critics, for whom that distance enabled him to provide a general biography with ease. All in all, distance could reasonably be regarded as a part of the work's authenticity; it is also a feature that shaped this biography's illusion of reality.

Conversely, the cover of JLB presents Jason Wilson as a Latin American scholar. The focus on his expertise in the region raises the question of whether this information on the biographer on the back cover grants the rewriter an unquestionable type of visibility. Indeed, the stress on the biographer's expertise seems to add to the book's illusion of intactness, that is, the illusion of total objectivity. Here one might ask why his personal connection with Buenos Aires is not mentioned on the cover, which would also contribute to the work's believability. In the following section, I will demonstrate how Jason Wilson compensates for the absence of this within the book. Yet from the outset, the publication seems to target an academically oriented reader with a specific interest in Jorge Luis Borges, rather than underscoring the biographer's personal affinity with the subject of the biography. Wilson's expertise tends to be a major factor in the work's authenticity, which is also highlighted by critics, who argue that by utilizing his scholarly skills, Wilson portrayed the Argentineness of Borges and offered quite a real image. However, despite celebrating his expertise, critics did not welcome all of his biographical interventions. This might lead us to assume that expertise does not always grant the rewriter the freedom to express his subjectivities in his rewrite. 


\section{The Illusion from Within: The Main Texts}

This section examines the authenticity of James Woodall and Jason Wilson in the texts themselves, and whether their subjectivities, as expressed in the context of publication, in paratexts and reviews, are in harmony with the way these individuals appear in their biographical narratives. For the sake of simplicity, the focus of analysis is limited to the biographers' respective discussions of the theme of "Borges and Perón".

TMMB elaborates on the matter that heavily affected Borges and his writing in two consecutive chapters titled "1939-1946: Great Fictions and Perón" and "19461955: Rising Fame". ${ }^{2}$ The biographer begins with the context that inspired Borges' seminal stories, namely "Pierre Menard", "Tlön", "La Biblioteca", "Las Ruinas Circulares", "La lotería", and "El Jardín". In doing so, Woodall harmonizes the subject's individual context with Argentina's political climate at the time. Right after noting that the jury of the 1941-42 National Prize overlooked Borges' story collection El jardín, Woodall explains the rise of nationalism in the country:

The mood in Buenos Aires at this time was divisive and unstable. Throughout the early 1940s, the army had begun to make its intentions plain. From 1943 on, puppet presidents ruled in Buenos Aires in a democratic vacuum, allowing one officer in particular to consolidate his position and influence in various ministries: Juan Domingo Perón was on the march. (124)

Following this information, the narrator turns to Borges' rising fame in Europe thanks to the French critic Roger Caillois. Yet he did not receive much support from the Argentine literary world. In those same years, Borges started to work for the Argentine publishing house Emecé as a pamphleteer and translator. The war in Europe and Hitler's fascism was about to end, "yet in Buenos Aires, the nightmare was about to begin", says Woodall, "a crowd gathered to hail the liberation of Paris was brutally dispersed, with injuries and fatalities" (129). This is one of the scenes in which the biographer becomes a mirror for Borges' feelings and he starts to embellish and fictionalize the historical facts with quite a dramatic tone of voice:

If Borges sensed relief at events unfolding in Europe, he felt only grave concern about what was in store at home. His problems would begin when it was plain that once Perón had acceded to the presidency, few had openly shared or would come to share that concern: Borges would remain something of a lone voice, on the political as well as the fictional fronts. (129)

In addition to the biographer's use of such words of self-expression as "sense" and "felt" on behalf of his subject without citing a statement by Borges to support them, he describes the author as "something of a lone voice" and omnisciently foreshadows what will happen once Perón assumes the presidency. We do not see the biographer as a separate individual but as an all-knowing narrator telling his story in a third-person

\footnotetext{
2 Borges' issues with Perón did not end in 1946, and Perón continues to appear in the later sections of the biography. For the sake of simplicity, I will discuss only these two sections, in which the politician frequently appears.
} 
narrative. Although this strengthens Borges' position in the story while hiding the biographer behind him, the detailed contextualization of the situation and the dramatic tone could be viewed as Woodall's idiosyncratic interventions to enhance the biography's believability.

According to Gerald P. Mulderig, one of the components of the biography's authenticity is the characterization of the subject as a real person of flesh and blood:

The believability that a biography achieves by conveying a unified image of its subject results, of course, from the biographer's selection and arrangement of his or her materials rather than from the data themselves. As Claude Lévi-Strauss has pointed out, individual pieces of information do not alone validate a historical text; they gain credibility only because they are consistent with a larger pattern of details established by the writer. (42-43)

Woodall's "invisible" idiosyncrasies in $T M M B$ could be listed as follows: he appears as an omniscient narrator; he characterizes his subject with dramatic descriptions; he identifies with his subject, and speaks and feels on his behalf; and he describes facts with a fictional style. These all add to the characterization of the subject as a clearly distinguished person. In this description of Woodall's authenticity, I would also include his peculiar contextualization of events: throughout the biography, we are given information on Argentine culture and history that many other Borges biographies do not provide. This is one of the reasons behind the greater length of Woodall's biography.

Following a year of political unrest, ${ }^{3}$ Perón was voted into office in 1946. In the chapter titled "1946-1955: Rising Fame", Woodall explains to his reader the reasons that led the Argentine people to embrace Perón as a saviour:

.... with his big smile, his radio-friendly voice, his slicked-back black hair, and not least of all his blonde mistress, Eva Duarte, whom he married on 22 October 1945, Perón stood for something every Argentine politician since 1930 had manifestly failed to offer: the charismatic possibility of achieving a new order without bloodshed or corruption. That Perón was able to unite, amongst his voters, a combination of old Argentine nationalism with new ideals of worker emancipation was adroit enough. That he could do it dressed up in the clothing of fascism, and make the entire package more than acceptable-devoutly to be desired, if the homilies of his millions of supporters were anything to go by-was little short of genius. As one contemporary account, describing the 17 October rally, put it, the Argentine people experienced 'collective orgasm' in welcoming back Perón. (133)

Towards the end of his depiction, Woodall breaks the chronology of the narrative and foreshadows that Perón would soon turn into a fascist. Then the biographer gets back to his subject: "Borges was appalled: '... a great number of Argentines are becoming

\footnotetext{
${ }^{3}$ In 1945, Argentina declared war on Germany, under pressure from the US. In the meantime, there were demonstrations against the Farrell regime, which had already been recognized by the Americans. At the time Perón was seen as a threat and imprisoned in Uruguay. However, this did not suppress the devotion of the Argentine people. In 1946, he came back and became the president of Argentina.
} 
Nazis without being aware of it,' he wrote in a Montevideo paper after Perón's release." (133-134). What awaited Borges was a troubled future:

In 1946, Borges' worst nightmare about the fate of Argentina became fact. It didn't stop him writing creatively; indeed, the apogee of his inventive powers, both in fiction and criticism, arguably still lay before him. But his life, which had not been easy until Perón, was now going to become ever more difficult. (134)

In 1955, the military took control and sent Perón into exile. Woodall starts Chapter Seven, titled "1955-1964: Borges Global", with the economic and scandalous reasons for this breakpoint: Evita had died of cancer, there were rumours of sex with teenage girls, Perón had interfered with the Catholic Church-which Woodall refers to as his "biggest mistake"-and set up Peronism as the state religion (173-174). The Revolución Libertadora had begun, but Peronism had grown deep roots in Argentina. Borges ignored the fact that the confrontation between the Peronists and the new leaders General Eduardo Lonardi and General Pedro Aramburu would have horrendous consequences for the economy and society. He continued to object to Peronist populism in any form. By doing so, he came into conflict with numerous leftist intellectuals. The author defended his stance against Ernesto Sábato in an article:

'Ethics', he wrote, 'do not stem from the State; something (he implies Peronism, but he means any form of populism) does not stop being atrocious just because thousands have proclaimed it, and acted it out. (175)

At this point, the biographer seems to leave his omniscience aside and starts to offer subjective justifications for Borges' conservatism. Woodall thinks that the author's stance against mass movements and democracy is based upon the "old-fashioned individualistic" doctrine that Borges inherited from his ancestors. "For a man who, apart from lecture tours inside his own country had not travelled away from the River Plate area since 1924", Woodall argues, "the world might indeed all too easily be seen in opposites of black and white" (175). For the biographer, Borges was too isolated to comprehend that "now, world politics, world ideologies, were much more complicated" (175).

However, Woodall also understands why the leftist intellectuals were at odds with Borges. During the Cold War, Latin America was facing "an anti-imperialist, economically protectionist fervour" and "impatience with Borges' species of oldfashioned individualism was inevitable, among intellectuals, at least" (175). "To stave off a deepening of Soviet influence", Washington and the capitals of Western Europe were encouraging right-wing fascism across Latin America and "inspiration for opposition and dissent was inevitably found in Marxism" (175). Here, Woodall introduces the "romantic guerilla" Che Guevara, who inspired all Latin Americans with "the figure of a maverick rebel" (176). Yet, despite this new political context, Borges kept fighting against leftism: 
The worst that can be said of Borges at this stage is that given his rising public stance, a trumpeted non-espousal of left-wing ideology, clearly associated with the cause of genuine liberation, might have been injudicious. This was to become particularly apparent in 1959, with the arrival of Fidel Castro and the Cuban Revolution; Ernesto Sábato and Ezequiel Martinez Estrada, amongst dozens of intellectuals of their generation, welcomed it. Borges, almost alone, considered it a disaster. (176)

Before coming this far in his narrative, Woodall had claimed that Borges' previous English-language biographer Emir Rodríguez Monegal was blinded by "a heroworship for his subject" (The Man 156). In fact, in many biographies the biographers declare themselves to be supporters of their subjects' beliefs and ideas. Yet Woodall does not choose this path and stands out as an independent individual able to observe the context differently from his subject. Although he tends to excuse Borges by portraying him as an apolitical old man who was "out of touch" and "took a literary old buffer's pleasure in being so" (176), he seems to suggest that the anti-Borges critics had their own reasons for criticizing the author as well. This once again highlights Woodall's distance from the source. His presence in the biography as an observer of both sides of the coin might be a product this situation.

Should this state of affairs lead us to the conclusion that James Woodall's narrative is a believable one from which the reader can infer the subjectivities of the biographer? Put differently, does this particular "translation" of Borges' life story allow for the visibility of its "translator", who, contrary to the assumption of the translation scholar Lawrence Venuti, ${ }^{4}$ ultimately produces a fluent account of his source?

The answer to all these questions could be "yes", which brings us back to the type of illusion of reality we find in Woodall's narrative. The biography seems to simulate a setting in which the reader is alone with the subject. Woodall applies many techniques, such as the dramatization of facts, third person omniscient narration, and foreshadowing, to facilitate the reading process. He also makes Argentine history and culture available to his English-language reader and describes the historical background to the events, which could also be considered an effort to familiarize the reader with the foreign context. While Woodall's descriptions bridge the gap between the reader and the biography's subject, and conceal the presence of the biographer in the process, the sections on politics seem to grant him a site of visibility. Although critics did not welcome these interventions, the occasional appearance of the biographer in the narrative does not seem to pose a threat to the biography's strong point, i.e. the illusion of immediacy.

Jorge Luis Borges by Jason Wilson was published ten years after James Woodall's book. In his introduction, the biographer promises the reader that he will relate the facts of Borges' life to the writer's literary vision. The biographer is aware that many people have written about Borges' life before him, and his aim is "not to rehash this research but to see how biography illuminates the work of this self-effacing man" (Jorge Luis Borges 7). Therefore, as he implies, literary criticism constitutes the backbone of $J L B$.

\footnotetext{
${ }^{4}$ Basing his theory on the Anglo-American literary context, Lawrence Venuti characterizes the prevailing standard of literary translation as "the more fluent the translation, the more invisible the translator, and, presumably, the more visible the writer or meaning of the foreign text" (Venuti, "Invisibility" 16).
} 
The twelve-page introduction gives us a hint of the concise and academic style of the biographer, who utilizes writings by Borges and his acquaintances as his sources. He does not seem to favour referencing secondary material. He categorizes literary and personal issues under two themes: The notion of the divided self, and Buddhism. While doing so, he refers closely to Borges' work: "Borges y yo", "El hacedor", "El Aleph", "La biblioteca de Babel", "La casa de Asterión", and the essay he co-authored with Alicia Jurado, "Qué es el Budismo?".

The theme of dual identity enables the biographer to introduce two different Borgeses: The man on the street, and the man at home. From the very beginning of the biography, we learn about Borges the introverted bibliophile along with Borges the public man through frequent references to the short story "Borges y yo". In just a few pages, the biographer manages to inform the reader about the awards his subject was and was not given, his perception of mirrors, labyrinths and masks, his ideas on readership, and the presence of Dante, Cervantes, Valery, Schopenhauer, and many others in his work.

Indeed, the inclusion of literary criticism in the introduction foreshadows what awaits the reader. Throughout the biography, Wilson describes his subject's life with a reference to a work or a statement by Borges himself. To give some examples, he discusses Borges' origins and criollismo with reference to the story "El sur" (26); explains Palermo and Borges' longing for his homeland while in Geneva through his "Cuaderno San Martin" and Evaristo Carriego (31); interprets the hotel in the story "La muerte y la brújula" as the one where the Borges family spent their summers (31); describes Borges' ambiguous feelings towards Geneva through Atlas and "Exposición de la poesía argentina" (41); talks about his friendship with Ramón Gómez de la Serna, who might be a real-life model for the poet Daneri in "El Aleph" (45-46); and describes his passion for the streets of Buenos Aires through Fervor de Buenos Aires (55).

These examples might lead us to assume that $J L B$ manifests an illusion of intactness; in other words, the illusion of full objectivity. This is partly the product of the biographer's scholarly background. Wilson's narration is certainly not always academic; on occasion he resorts to the features of commercial biography, the most common of which is his dramatic description of facts. However, in general, Wilson's narrative reflects his reputation as a Borges critic, and this seems to foreground the objectivity and reliability of the book as its key feature. The main text of his book begins with these sentences:

I met Borges briefly and formally several times; I heard him give his idiosyncratic talks in London, Boston and Buenos Aires. I have written on him as a literary critic and drafted the anonymous obituary for The Times (Jorge Luis Borges 7). ${ }^{5}$

In the subsequent paragraphs, the biographer compares the above-mentioned obituary he wrote for The Times with Borges' 1974 mock self-obituary, which claimed to be a note in Encyclopedia Sudamericana to be published in 2074. He elaborates on what Borges' note did not mention but Wilson's version included. These are: What he wrote before the 1940s; his mother Leonor Acevedo; his sister's husband Guillermo

\footnotetext{
${ }^{5}$ The biographer does not present his acquaintance with Borges as an advantage. On the contrary, in subsequent passages, he supports his arguments by emphasizing that reading Borges was more important than knowing him in person (7). Still, in my opinion, his reference to the moment that he met the master in person adds to the confident tone that he maintains throughout the biography.
} 
de Torre; and his scandalous love affairs. The scholar concludes that the author was simply tired of what made him Borges (13). By doing so, Wilson seems to imply that he is capable of getting into the mind of his subject and that he understands Borges' authorial decisions.

$J L B$ introduces Juan Perón only after the first eighty pages of the 130-page main text. Unlike James Woodall, who enjoyed narrating the reasons behind the rise of Peronism with the dramatic tone of a journalist, Jason Wilson describes the period between Borges' birth and the 1940s with little reference to the turbulent politics of Argentina; ${ }^{6}$ instead, he focuses on the literary developments in Europe and Argentina that had an effect on Borges' writing. We could thus say that whereas Woodall used the historical context to understand his subject, Wilson utilized the author's writings to reach Borges.

In Chapter Four titled "The 1930s, Crisis and Accident", Wilson enters the political context of the 1930s. This section accounts for Borges' reaction against the socioeconomic decay in Argentina triggered by the Great Wall Street Crash of 1929. "The fun was taken out of literary life", as Wilson reads into his subject's mind: "Borges reacted to events by becoming a supporter of the Radical Party's political boss Hipólito Yrigoyen" (85). This decision surprises Wilson, because the party represented the middle class and immigrants, and Borges had never been on good terms with either; his family belonged to the elite that had lost power in Argentina long before. Parenthetically, the biographer foreshadows Borges' decision to join the Conservative Party in 1963 and to leave it shortly thereafter (86). We do not see any reference to Borges' work in this one-paragraph explanation of Borges' becoming an Yrigoyenista until Wilson concludes it with a letter by his subject, whereby the biographer explains Borges' support of Yrigoyen: "he represented 'Argentine continuity', was a porteño gent, and lived in a modest house on calle Garay-a talismanic street referred to in the stories 'The South' and "The Aleph" (86).

Following the description of Borges' political activities in the early 1930s, Wilson explains the depression that his subject fell into with his poem titled "Adrogué", named after the hotel in which Borges attempted to kill himself with a pistol. According to the biographer, the reason for this psychological breakdown could not possibly be the political situation but his "general state of love-sickness" (Jorge Luis Borges 84-85). In the subsequent pages, we learn that Buenos Aires was not a city full of love either: It had become the capital of the white slave trade, a Babylon "packed with sex-starved male immigrants dancing the tango in queues for whores" (86). Wilson describes how this social change affected Argentine literature by making reference to other Argentine writers. In Wilson's account, as a result of the city's lovelessness, Borges, in his "lumpy body", suffered "recurrent feelings of self-disgust" (86). This is where the scholar gets dramatic and portrays his subject as a poor soul "wounded by love, [who] retreated from his body into his mind and read all the more" (Jorge Luis Borges 87).

The infusion of drama into the narration of historical facts surely adds to the believability of the biography. Although scholarly by nature, Wilson's description of

\footnotetext{
${ }^{6}$ Before page 106, Wilson refers to the political issues in the country in two places: First, while describing the 1930s, he briefly mentions the effects of the Wall Street Crash on the Argentine economy and the rise of fascism in the country afterwards (85). Secondly, in the same chapter, he introduces the people involved in the literary journal Sur, who were known to be anti-Peronists and supporters of the Allies during the war against Hitler (95). Apart from these two hints to the political climate before the 1940s, Wilson adopts a more individual perspective than Woodall, and his narrative focuses on certain relations that he draws between Borges' work and the individuals around him.
} 
Borges' issues with love seems to enable the biographer to portray a real human of flesh and blood.

His description of the theme of Perón, however, does not have the same dramatic tone. In $T M M B$, Woodall introduces the politician with the tone of an enthusiastic journalist: "with his big smile, his radio-friendly voice, his slicked-back black hair, and not least of all his blonde mistress"; for Woodall, "Perón stood for something every Argentine politician since 1930 had manifestly failed to offer" (133). But Wilson focuses directly on the consequences of the rise of Perón for the lives of Borges family members, with no explanation of what Perón meant to the Argentine masses. Rather than providing the reader with a contextual overview of the political situation, the biographer chooses to stick to the individual context of his subject. He directly initiates a discussion on Borges' anti-Peronism through the matter of the 1942 National Prize, which Borges did not win because the jury had found him "too cerebral, too dehumanized"; Wilson states that this is observable in the story "El Aleph" (Jorge Luis Borges 115). Below is the biographer's telling of Perón's rise to power:

However, in 1946, after nine years, as a consequence of Perón's rise to power and popularity through elections, Borges was demoted from the Miguel Cané library to inspector of poultry, eggs and rabbits at a market on avenida Córdoba, because, Borges discovered, he had sided with the Allies in the war. This demotion was Perón's 'macho humiliation' of Borges, according to a biographer Emir Rodríguez Monegal. Borges had turned into a politicized anti-Peronist. His position coincided with his defence of Western civilization against xenophobic nationalism. (116)

In the subsequent paragraphs, Wilson returns to the effects of Peronism on Borges and his family. He seems to be aiming for an action-based narrative that lacks value judgments. We do not see this objective attitude in the sections on the writer's love life and shy personality. In the following quote, the biographer leaves the Borges' context aside for a moment and gives us information about Perón's supporters:

All the later 1940s Borges wrote and lectured under the threat of Perón, who had had Borges removed from the library in 1946. Perón, admirer of Mussolini, came into power with a coup in 1943, backed by the unions and the poor. By 1945 his power base was the urban proletariat, the cabezas negras (blackheads) and Evita's descamisados (shirtless ones). Borges, when he lost his library sinecure, was now a Sur writer, united behind the cosmopolitan group through their anti-Peronism. In 1948 Borges's mother Leonor and sister Norah were arrested on calle Florida for insulting Evita and Perón, and then singing the National Anthem. They did have pamphlets on them objecting to changes in the constitution. (120)

Wilson adds a bit of flavour to his event-based narration of politics while recounting the 1955 coup that overthrew Perón. As he states, "like many of the middle class urban anti-Peronists", Borges "took to the streets and became hoarse with shouting" (130). He then goes on to the matter of his subject's blindness, which "terminated his creative bout and his amazing fictions and essays": "That he could not read what he had just written was the final straw" (130). 
Indeed, compared to his depictions of Borges' private life, which the critics found quite harsh and subjective, Wilson manifests his individuality even more in the sections focusing on his own field of expertise, which is literature. We see parentheses as sites of visibility that enable him to share his personal opinions. Examples are as follows: Borges the lecturer, "with his fast, hoarse way of talking, became part of the public image (far easier to listen to Borges than to read him)" (120); under the title Otras inquisiciones, the author compiled a group of essays that "jump around from Kafka to Wells, W. H. Hudson, Pascal, Keats, Beckford, Coleridge, Quevedo, Wilde, Américo Castro in unpredictable, quirky ways (who on earth would group those authors?)" (128).

On occasion, the biographer comments on his subject using the first-person pronoun. He examines Borges' life in the 1930s in Miguel Cané library as follows:

Year of 'solid unhappiness', he wrote. I see a slow retreat into innerness, away from grappling with reality, partly because of his diminishing eyesight, partly a response to the depressing world of local politics and the Second World War in Europe. (106)

In the example below, we see Wilson taking a step further. While explaining the plot of "Death and the Compass", he offers his own selection of adjectives over the ones Borges used in the story:

It's set in a dreamy Buenos Aires, partially in the infamous Paseo de Julio and then in a hotel in Adrogué, with its 'interminable' scent of eucalyptus trees (that 'interminable' is a typically odd Borgesian adjective; l'd have written 'pervasive'). (111)

In the quote below, Wilson expresses doubt about Edwin Williamson's (one of Borges' previous English-language biographers) interpretation of Borges' crush on Norah Lange:

If Norah Lange was indeed the love of Borges's life (which I doubt), this would have been the final nail in the coffin, although she had brushed him aside ages before. Did the affair with Estela Canto bury this earlier wound? I believe it did, but he wrote a strange story about not being able to forget called 'The Zahir', on the surface another tale about his insomnia, like 'Funes, His Memory', generated by his accident and fear of losing his mind. (127)

The biographer's interpretation of the relationship between Borges and Norah, using the phrases "I believe" and "I doubt", seems to imply that on his path to truth, he sometimes uses his intuitions as a source. There is no exact proof for this, but for Wilson, Norah was not the love of Borges' life. His affair with Estela had helped him to forget her. 
At the beginning of the article, I proposed the illusion of total representation as a feature that reveals the rewriter's subjectivity, rather than his absence in his rewrite. I suggested that illusion is not merely a rhetorical feature, but a construct that concerns both the text and its context. As demonstrated here, my two case studies, James Woodall and Jason Wilson, took different paths to create the illusion of reality in their biographical journeys.

Both the paratexts and reviews bear the traces of the remarkable distance between James Woodall and his subject. The critics do not view this as a disadvantage; on the contrary, Woodall's distance is assumed to have contributed to the ease of the narrative. And clearly, the fluency in Woodall's biography also has to do with the intended reader of the book. In line with the publishing policy of his publisher, the biographer preferred to make the foreign product available to the target reader through his dramatic descriptions and detailed contextualizations, all of which contributed to the illusion of reality in Woodall's representation. The Man in the Mirror of the Book is thus an example of the illusion of immediacy in biography.

Just as Woodall's distance from his subject contributes to the authenticity of The Man in the Mirror of the Book, Jason Wilson's Jorge Luis Borges owes its authenticity to its biographer's agency. Wilson uses his expertise as a scholar of Latin American Studies and infuses his narrative with an illusion of intactness through his objective interpretations of facts. The main narrative seems to work together with the paratexts and reviews, which also highlight the way Wilson reflected his expertise in his narrative.

Of course, neither Woodall nor Wilson felt the obligation to stick to the form of illusion manifest in their biographies. Just as Woodall appears as an expert who assures his reader of the reliability of the text in some sections of $T M M B$, on occasion Wilson appears as a subjective biographer who includes dramatic descriptions of facts, as well as his personal opinions, in his narrative. I would suggest that these also contribute to the authenticity of their "total" rewrites. All in all, as I have aimed to demonstrate in this study, each rewriter shapes his own illusion of reality.

\section{Works Cited}

Aizenberg, Edna. “Jorge Luis Borges." Revista de estudios Hispanicos 43, 2009, pp. 442-443.

Borges, Jorge Luis. Labyrinths. Translated by Donald E. Yates \& James E. Irby, New Directions, 1964.

González Echevarría, Roberto. "Man Without a Life." The New York Times, 31 August 1997 ,

archive.nytimes.com/www.nytimes.com/books/97/08/31/reviews/970831.31gonz01.h tml. Accessed 10 July 2018.

Hodder \& Stoughton. www.hodder.co.uk. Accessed 26 May 2018.

Lefevere, André. Translation, Rewriting, and the Manipulation of Literary Fame. Routledge, 1992.

Mars-Jones, Adam. "If All Literature is Autobiographical, the Notion of Autobiography Comes Close to Being Meaningless." The Observer, 21 Jun 1996, p. 15. 
Mulderig, Gerald P. "Telling Life Stories: The Rhetorical Form of Biographical Narratives." Life Writing: Autobiography, Biography, and Travel Writing in Contemporary Literature, edited by Koray Melikoğlu, ibidem-Verlag, 2006, pp. 35-47.

Pearson, Lon. “Jason Wilson, Jorge Luis Borges.” Chasqui, 38(2), 2009, pp. 230-231. Pindar, Ian. "Watched Pots: Jorge Luis Borges by Jason Wilson." The Guardian, 26 August 2006, www.theguardian.com/books/2006/aug/26/jorgeluisborges. Accessed 26 March 2018.

Reaktion House. www.reaktionbooks.co.uk. Accessed 26 May 2018.

Schifino, Martin. "Best Before His Blindness." Times Literary Supplement, Apr. 4, 2008, p. 27.

Sexton, David. "No sex please, he's nearly British." The Spectator, 29 Jun 1996, pp. 29-31.

Stavans, Ilan. "Bi(bli)ographies: The Remains of Jorge Luis Borges." Transition, no. 74, 1997, pp. 62-76.

"The Man in the Mirror of the Book: A Life of Jorge Luis Borges." The Economist, 20 July 1996, p. 7.

Venuti, Lawrence. "The Translator's Invisibility: The Evidence of Reviews." In Other Words: Journal of the Translator's Association, no. 4, 1994, pp. 16-22.

Wilson, Jason. "Books: Life Member of the Gaucho Club." The Independent, 6 Feb. 1999, www.independent.co.uk/arts-entertainment/books-life-member-of-thegaucho-club-1069037.html. Accessed 26 May 2018.

---. Jorge Luis Borges. Reaktion Books, 2006.

---. "Becoming a Hispanist." New Spanish Books, www.newspanishbooks.com/feature-article/jason-wilson-becoming-hispanist. Accessed 26 May 2018.

Wong, Nicholas. "The Man in the Mirror of the Book: A Life of Jorge Luis Borges." Contemporary Review, no. 271, Sept. 1997. www.thefreelibrary.com/The+Man+in+the+Mirror+of+the+Book\%3A+A+Life+o $\mathrm{f}+$ Jorge+Luis+Borges.-a020236236. Accessed 6 November 2018.

Woodall, James. The Man in the Mirror of the Book: A Life of Jorge Luis Borges. Hodder \& Stoughton, 1996. 